\title{
Liquidity vs. Efficiency in Liberalized International Financial Markets: a Warning to Developing Economies
}

\author{
Liquidez vs eficiência nos mercados financeiros internacionais \\ liberalizados: um alerta para as economias em desenvolvimento
}

PAUL DAVIDSON*

RESUMO: Até 1973, o sistema de pagamentos internacionais do pós-guerra foi, em grande medida, moldado pela tese de Keynes de que as taxas de câmbio flexíveis e a livre mobilidade internacional de capital são incompatíveis com o pleno emprego global e o rápido crescimento econômico em uma era de livre comércio multilateral (Felix, 1977-8) . Isso resultou em um sistema monetário internacional estável que permitiu que a economia global experimentasse um crescimento econômico e prosperidade sem paralelo, apesar dos controles de capital generalizados e das regulamentações do mercado financeiro internacional. Desde 1973, o sistema financeiro tem se tornado cada vez mais frágil, com crises recorrentes e cada vez mais estressantes da dívida internacional e da liquidez da moeda, ameaçando a estabilidade da economia global.

PALAVRAS-CHAVE: Regime cambial; eficiência de mercado; incerteza.

ABSTRACT: Until 1973 the postwar international payments system was, in large measure, shaped by Keynes's thesis that flexible exchange rates and free international capital mobility are incompatible with global full employment and rapid economic growth in an era of multilateral free trade (Felix, 1977-8). This resulted in a stable international monetary system that permitted the global economy to experience unparalleled economic growth and prosperity despite widespread capital controls and international financial market regulations. Since 1973, the financial system has grown progressively more fragile with recurrent and increasingly stressful international debt and currency liquidity crises threatening the stability of the global economy.

KEYWORDS: Exchange rate regime; Market efficiency; uncertainty .

JEL Classification: E12.

\footnotetext{
* Holly Chair of Excellence in Political Economy, University of Tennessee, United States. E-mail: pdavidso@utk.edu.
} 


\section{WHY THE CHANGE SINCE 1973?}

Keynes's incompatibility thesis is directly derivable from his General Theory - an analysis of a money-using, market-oriented, entrepreneurial economy, where liquidity played an essential role in determining real spending decisions. Unfortunately, despite the adoption of many Keynesian policies in the years after the war, Keynes's analytical system was never incorporated into orthodox economic theory. Accordingly, by the 1960s, mainstream classical economists were developing closed and open economy models based on three classical axioms that Keynes had suggested were too restrictive for a general theory of employment. ${ }^{1}$ By invoking these restrictive classical axioms, a special case model was resurrected whose "characteristics happen not to be the economic society in which we live with the result that its teaching is misleading and disastrous if we attempt to apply it to the facts of experience" (Keynes, 1936, p. 3).

This special case classical (supply-side) model demonstrated that Keynes's in compatibility thesis was wrong since markets are efficient. Optimum global eco nomic growth, therefore, requires a laissez-faire approach to market activities with flexible exchange rates, free trade and free international capital mobility. This special case claims that any regulation to limit financial flows (whether of cross-border capital flows or within a nation) imposes huge costs on society. Free the banking system and all financial markets from onerous government oversight and regulation and, policy makers were assured, a world of heavenly economic bliss would envelop the planet. ${ }^{2}$

Neoclassical Synthesis (or Old) Keynesians had already adopted microfoundations developed by Samuelson (1947) that invoked the three classical axioms that Keynes rejected (Davidson, 1984). Joan Robinson dubbed the progeny of this unfortunate marriage of classical axioms with Keynesian macroeconomic jargon and policy "Bastard Keynesianism". The logical inconsistency between their micro foundations and their macroeconomics made these Bastard Keynesians easy prey for the classical counterrevolution. Nevertheless, this successful academic resurrection of the classical system would have not been sufficient to alter the policy mix if it were not for events of the 1970s.

The 1973 oil price shock created huge international payments imbalances and unleashed inflationary forces in oil consuming nations. The resulting economic dislocation placed policy makers in a difficult position. Without having to admit that they did not know what to do, policymakers threw away the institutions that had accommodated Keynes's incompatibility thesis and used the 1960s classical model to rationalize their behavior. Then if anything went wrong, policy makers

\footnotetext{
${ }^{1}$ These classical axioms are (1) The neutrality of money axiom, the gross substitution axiom, and the ergodic axiom. See Davidson (1983).

${ }^{2}$ Only the supply side limitations of available resources and the level of technical progress would prevent the immediate achievement of a Garden of Eden on Earth.
} 
could suggest that they could not be blamed — for, after all, the efficient marketplace "knows" best as Nobel prize winners Friedman ${ }^{3}$,Lucas, Merton and Scholes continually assured us.

The exchange rate itself became an object of speculation. Since the mid-1970s, international financial transactions have grown substantially faster than the growth in international trade (Felix, 1997-8). International financial flows dominate trade payments. Currently banks transact over $\$ 1.5$ trillion daily in foreign exchange markets, almost 70 times the volume of daily international trade in goods and services. Exchange rate movements reflect changes in speculative positions rather than changes in trade patterns.

Since the 1970s, Tobin (1974) has been almost the only voice with significant visibility in the economics profession warning that free international financial markets with flexible exchange rates can be extremely volatile and therefore can have a "devastating impact on specific industries and whole economies" (Eichengreen, Tobin and Wyplosz, 1995). Exchange rate movements affect the international competitive position of domestic vis-à-vis foreign industries and therefore tend to depress the inducement to invest in large projects with irreversible sunk costs. Volatile exchange rates undermine entrepreneurs' confidence in their ability to appraise the potential profitability of any large investment project. Every exchange rate increase not only threatens domestic industries with significant loss of exportmarket share but also home-market share loss, as imports become less expensive. Managers realize that any upward blip in the exchange rate during the lifetime of any contemplated investment project can saddle their enterprises with irreversible costly idle capacity. Downward blips can reduce expected real profits. Consequently, the marginal efficiency of investment is reduced (cf. Pindyck, 1991, p. 1139). The greater the uncertainty regarding future exchange rates, the less investment globally- just as Keynes's (1936, ch. 17) analysis of liquidity preference and investment predicted.

Since 1973, trade and real investment spending in open economies have become the tail wagged by the international speculative exchange rate dog. Consequently, the annual growth rate in investment in plant and equipment in OECD nations fell from $6 \%$ (before 1973) to less than 3\% (since 1973). Less investment growth means a slower economic growth rate in OECD nations (from $5.9 \%$ to $2.8 \%$ ) while labor productivity growth declined even more dramatically (from $4.6 \%$ to $1.6 \%)$.

\footnotetext{
${ }^{3}$ In a recent article in the Wall Street Journal, Friedman (1998) argues that with market determined exchange rates, exchange rate pressures will always be dissipated, despite the long-known argument that in the absence of the Marshall-Lerner condition, market forces would exacerbate exchange rate problems. For a further discussion see Section V infra.
} 


\section{ALTERNATIVE THEORIES OF FINANCIAL MARKETS}

Are capital and exchange rate markets inherently destabilizing and fragile or is today's financial fragility the result of market "liberalization" policy decisions taken since 1973? In these days of Asian contagion, Russian bears, and reeling Brazilian reais, we are being haunted by Minsky's frightening financial fragility question "Can it happen again?".

Peter L. Bernstein is the author of the best-selling book Against The Gods (1996), a treatise on risk management, probability theory and financial markets. Bernstein noted that since World War II "the number of stock markets around the world has grown from 50 to just over 125 - even the Chinese, nominally still socialists, have seen fit to establish stock markets on their territory". Accordingly, one might first ask: if financial markets are, as Minsky suggests, so fragile and destabilizing, why are so many emerging economies using them?

How one responds to these queries depends on the underlying economic theory that one explicitly, or implicitly, utilizes to explain the role of financial markets in an entrepreneurial economy. There are two major alternative - and incompatible - theories of financial markets: (1) the classical efficient market theory (hereafter EMT) and (2) Keynes's liquidity preference theory (hereafter LPT). Proponents of EMT urge liberalization of financial markets, while those favoring LPT suggest the need for vigilant regulation with institutions and rules constraining and affecting the behavior of market participants.

EMT is the backbone of conventional economic wisdom whose mantra is "the market knows best" how to optimally allocate scarce capital resources and promote maximum economic growth. This EMT view is succinctly epitomized in US Treasury Secretary Summer's statement: “the ultimate social functions [of financial markets are) spreading risks, guiding the investment of scarce capital, and processing and disseminating the information possessed by diverse traders... prices will always reflect fundamental values... The logic of efficient markets is compelling" ${ }_{4}$ (Summers and Summers, 1989, p. 166).

In contrast, the logic of Keynes's $L P T$ is that the primary function of financial markets is to provide liquidity for asset holders. Since a liquid market must be an orderly one, rules and institutions must be developed to guarantee orderliness. If Keynes's LPT of orderly financial markets is relevant, then financial markets can never deliver, in either the short- or long-run, the efficiency promises of EMT. In the real world, efficient markets are not liquid and liquid markets are not efficient.

Bernstein argues that EMT is not the relevant theory for the world in which we live. Bernstein states "The fatal flaw in the efficient market hypothesis is that there is no such thing as an [efficient] equilibrium price... [and] a market can never be efficient unless equilibrium prices exist and are known" (1998b, p. 8, emphasis in original; also Bernstein, 1998a). Bernstein (1998b, p. 7) endorses Keynes's LPT

\footnotetext{
${ }^{4}$ In an EMT world, economic fundamentals such as price/earnings ratios determine stock market prices.
} 
as the relevant explanation for the global growth of financial markets when he argues "a stock market without liquidity ceases to be a market".

\section{CLAIMS OF EFFICIENT MARKET}

\section{ADVOCATES AND THE POSTWAR FACTS}

Since the 1970s, EMT has provided the rationalization for dismantling the ubiquitous postwar regulations of financial markets. Liberalization, it is claimed, produces lower real costs of capital and higher output and productivity growth rates compared to postwar till 1973 growth rates experience when international capital flow controls were practiced by most countries of the world, including the United States. ${ }^{5}$ Do the facts support this EMT argument for financial liberalization?

Comparing the historical record since 1700, Adelman (1991) has characterized the postwar pre-1973 period as a "Golden Age of Economic Development... an era of unprecedented sustained economic growth in both developed and developing countries". Adelman (1991, p. 15) found that the average annual growth rate of OECD real GDP per capita from 1950 till 1973 was "almost precisely double the previous peak growth rate of the industrial revolution period. Productivity growth in OECD countries was more than triple (3.75 times) that of the industrial revolution era". The resulting prosperity of the industrialized world was transmitted to the less developed nations (LDCs) through world trade, aid, and direct foreign investment. From 1950- 73, average growth in per capita GDP for all LDCs was 3.3 per cent, almost triple the average growth rate experienced by the industrializing nations during the industrial revolution. Aggregate GDP of the LDCs increased at almost the same rate as that of the developed nations, 5.5 per cent and 5.9 per cent respectively.

Since 1973 the world's real GDP per capita has been less than $1.5 \%$, while as already noted, OECD real GDP per capita growth, investment in plant and equipment, and labor productivity growth rates declined by more than half of the rates experiences before liberalization. Clearly financial liberalization since 1973 has not produced the achievements its advocates claimed. Global financial market performance has been fragile. The global economy has stumbled from one economic liquidity crisis to another, e.g., the 1970s stagflation, the 1980s Latin American and African debt-liquidity problems, and the 1990s international currency crises, i.e., the 1992 EMS currency crisis, the 1994-5 Mexican pesos crisis, the 1997 Asian crisis, the 1998 Russian debacle, and 1998-9 Brazilian crisis. Despite liberalization, for most nations, economics has once more become the dismal science.

\footnotetext{
${ }^{5}$ In July 1963, the United States introduced the Interest Equalization Tax [IET] on purchases by residents of foreign (other than Canadian), fixed-rate securities. The tax rate varied from zero to 150 basis depending on maturity. In August 1971 dollar convertibility was suspended and in 1973 Nixon closed the gold window. In 1974 the IET was formally abolished.
} 


\section{A LESSON FROM THE GOLD STANDARD ERA}

From 1880 to 1914, the gold standard provided the world with a fixed and credible exchange rate system. During this period there were many banking crisis "but they rarely turned into currency crises, except at the Latin American periphery... despite very large international capital flows" (Skidelsky, 1998, p. 3). Even though defaults occurred, global investment continued as London, acting as the clearing house for international trade, made "sterling the main vehicle currency in both international payments and investments. It was the absence of alternative currencies to hold that reduced the speculative element in short-term money flows" (Skidelsky, 1998 , p. 5, emphasis added).

In this period, bouts of inflation, unstable political conditions and revolution, or a collapse of export (commodity) prices led to recurrent currency crises in the Latin America periphery. But "debt collectors moved in, with rescheduling and fresh loans... as soon as service on the bonds was resumed, the investors came back... The crucial point in all this was that the gold standard was stable at the centre, unstable at its Latin American periphery... As a rule, currency crisis hit second class countries, not first-class ones" (Skidelsky, 1999, pp. 8-9). ${ }^{6}$

This changed in the interwar period when international capital flow crises struck the core countries as well as the periphery. In the 1920s even as core countries attempted to return to the gold standard, the resulting exchange rate peg was not credible. Competition between financial centers in London, Paris, and New York made multilateral clearing cumbersome and difficult, especially when there were persistent imbalances in international payments. Only the continual recycling of U.S. current account surplus by American banks prevented the collapse of the world economy. Meanwhile the United States adopted tariffs that made it very difficult for Europeans to run a balanced trade position or to earn dollars to repay postwar dollar loans. In 1928 when U.S. funds were diverted from international loans to Wall Street speculation, the international payments system started to crumble. Money began flowing from deficit to surplus countries as reserves were liquidated to service debts to the United States. When commodity prices collapsed, the periphery defaulted on these loans - but this time "the contagion spread to Europe" as Germany tried to balance its international payments by severely depressing its economy. As unemployment rose drastically, a German default occurred in 1931. "A deflationary hurricane swept over the world, as investors scrambled for liquidity" (Skidelsky, 1998, p. 13). Huge speculative waves attacked the core currencies. Interbank credits could not stem these assaults. The result was to end private foreign investment flows for decades. Can this happen again as the euro and the yen compete with the US dollar as an international reserve currency especially if the

\footnotetext{
${ }^{6}$ Does not this experience appear to have some similarities to events in the post-1973 era when the world was on a dollar standard?
} 
world's largest debtor slips into recession in the near future and the world relies on liberalized financial markets to finance payments imbalances?

\section{PROPOSED CONVENTIONAL SOLUTIONS}

Minsky $(1972,1975)$ argues that financial markets are inherently fragile and destabilizing. Old and New Classical economists, on the other hand, believe in the absolute robust efficiency of free financial markets where speculation is inherently stabilizing. Mainstream Keynesians appear to be trying to keep one foot in the Minsky camp and the other in the classical camp. They argue that information about the future is difficult and costly to obtain and therefore, at least in the short run, a flexible exchange rate system can be destabilizing.

Consequently, there is a search for a "third way" occupying the middle ground between the Minsky view that markets are inherently fragile and the classical view that financial markets are always efficient and speculation is stabilizing. This "third way" approach has become the conventional wisdom of America's "New Democrats", Britain's “New Labour" and Germany's "New Social Democrats" political leaders and their economic advisors. The third way admits that in the long run free markets are efficient and stable (i.e., revert to the mean) but, in the short run, 20th century free-market capitalism has not quite yet attained the state of perfection claimed by New Classical theorists. Accordingly, there is a role for a small army of skilled technicians (recruited from the graduate students of third way economics professors) who, by making information readily and inexpensively available, will keep the efficient free market machine from being pushed off of its tracks by scoundrels, wastrels, shirkers, cronies, and fools.

The financial instability of the Asian tigers and other peripheral nations is attributed to the lack of transparency, i.e., the difficulty of obtaining full information regarding the foolish actions of bankers, capitalist cronies, dishonest and/or incompetent government employees, etc., who flourish in a world of asymmetric information. For example, at a 1998 conference at the Jerome Levy Institute on the "fragility of the international financial system", the then Federal Reserve Vice-Chair Alice Rivlin recommended a policy involving "two key prescriptions, one relating to transparency" and the other "increased supervision and monitoring of emerging financial markets". Rivlin's two keys imply that sufficient transparency and Central Bank auditing procedures (similar to what exists in the U.S. banking system) is the policy fix for the financial fragility of emerging markets. The Federal Reserve (but apparently not the Bank of Japan), one is lead to believe, has the fragility problem well in hand. In Euroland, the Bundesbank also had the situation well in hand, but there are doubts about the new European Central Bank.

No one can be against more information and uniform public auditing procedures to prevent criminal fraudulent practices. Financial fragility, however, would not disappear in a world of uncertainty if only we have more transparency. After the Mexican crisis of 1994-5, the World Bank and the IMF, as well as the U.S. Tre- 
asury and the Fed, had professional technicians continually monitoring financial activities occurring in Southeast Asia, Russia, and Brazil. Despite the scrutiny of all these professionals, no warning flag was apparently raised within their respective agencies until after each crisis developed. Nor did the transparency, banking regulations, auditing controls, and uniform bankruptcy laws of the United States prevent (1) the 1982 oil patch crisis from threatening major US banks such as Continental Illinois,(2) the mid-eighties Savings and Loan Bank crisis, and (3) the 1998 Long Term Capital Management hedge-fund crisis. In all these cases, only after the crisis developed, did US authorities take action, e.g., the "too big to fail" doctrine in the first case, the Resolution Trust Company in the second, and brokering of an equity takeover of Long Term Capital Management by a syndicate of its bankercreditors. This evidence suggests that transparency, oversight, and market discipline at one does not solve financial market instability problems. To be for transparency and discipline is the moral equivalent of being for motherhood and peace. No self-righteous person can be against motherhood, and by implication neither can one be against the provision of more information, i.e., transparency. ${ }^{7}$ Transparency per se, however, is not the solution, for as The Economist (March 13, 1999, p. 90) notes, the term "transparency" is merely jargon an economist invokes to "regain the initiative" whenever "an economist is falling behind in an argument".

Despite their willingness to accept the "compelling logic" of EMT, the common sense of Old Keynesian Tobin and some of his New Keynesian followers such as Summers (1989) and Stiglitz (1989) regarding real world financial markets can not help but break into their logical models - with injury to their logical consistency. To solve today's international monetary problems, these Keynesians, at least in their academic writings, have advocated a "Tobin tax" where governments limit market volatility by increasing the transactions costs on all international payments via a small ad valorem tax (Tobin, 1974). Unfortunately, though Tobin's assessment of the problem is correct, the empirical evidence is that any increase in the financial transactions costs significantly increases rather than decreases measured market volatility (Davidson, 1998). Moreover, a Tobin tax does not create a greater disincentive for short-term speculators than for long-term traders as some have claimed (Davidson, 1997). Hence, the "Tobin tax" solution is the wrong tool to solve the growing international financial market volatility problem.

Since the Mexican peso crisis of 1994, pragmatic policy makers have advocated a lender-of-last-resort (LOLR) as crisis manager to stop international financial market liquidity hemorrhaging and to "bail-out" the international investors, des-

\footnotetext{
${ }^{7}$ The sound bite word " transparency", however, is a canonization of the misleading and potentially devastating New Keynesian economic position that markets wouldbe efficient in the shortrun except for the fact that reliable full information about the future is not free. In other words, asymmetric information driven-behavior is a prime cause of the current financial market crises that have devastating real impacts. In my recent invited lecture to a plenary session of the Royal Economic Society (Davidson, 1998) I developed why I believe this asymmetric information scenario is logically inconsistent as well as inapplicable to the world in which we live.
} 
pite the moral hazard problem these bail-outs are supposed to cause. In 1994, US Treasury Secretary Rubin encouraged President Clinton to play this LOLR role. With Clinton's liquidity facilities exhausted, the IMF stepped into this lender role when the Asian crisis of 1997 and the Russian default occurred in 1998. When the IMF appeared to be near the end of its liquidity rope after the Asian, Russian and Brazilian crisis, IMF Director Stanley Fischer (1999) suggested that the G-7 nations provide financing for an international lender of last resort (LOLR). Fischer's cry for a G-7 LOLR collaboration is equivalent to recruiting a volunteer fire department to douse the flames after someone has cried fire in a crowded theater. Even if the fire is ultimately extinguished there will be a lot of innocent casualties. Moreover, every new currency fire requires the LOLR to pour more liquidity into the market to put out the flames. The goal should be to produce a permanent fire prevention system, not to rely on organizing larger and larger volunteer fire fighting companies with each new currency crisis. In other words, crisis prevention rather than crisis management should be the policy goal.

Economists Rudi Dornbusch and Steven Hanke have recommended a currency board solution for Latin American and Asian nations. A currency board fixes the exchange rate so that the domestic money supply does not exceed the amount of foreign reserves a nation possesses. ${ }^{8} \cdot$ Thus, if and when investors panic and rush to exit from a nation, the currency board maintains the exchange rate by selling foreign reserves and reducing the domestic money supply by an equivalent sum. A currency board solution, therefore, is equivalent to the bloodletting prescribed by 17 th century doctors to cure a fever. Enough blood loss can, of course, always reduce the fever but often at a terrible cost to the body of the patient. Similarly, a currency board may douse the flames of a currency crisis, but the result will be a moribund economy.

Milton Friedman, Jeffrey Sachs and others have suggested a return to completely flexible exchange rates. Unfortunately, whenever there is a persistent international payments imbalance, free market exchange rates flexibility can make the situation worse. For example, if a nation is suffering a tendency towards international current account deficits due to imports exceeding exports, then free market advocates argue that a decline in the market price will end the trade deficit. If, however, the Marshall-Lerner condition does not apply, then a declining market exchange rate worsens the situation by increasing the magnitude of the payments deficit. ${ }^{9}$

\footnotetext{
${ }^{8}$ A currency board is the modem equivalent of the gold standard where the U.S. dollar is gold. The gold standard worked only when there was no bandwagon effects. It always failed when there was a bandwagon effect for a fast exit.

${ }^{9}$ The Marshall-Lerner condition requires that the sum of the price elasticities for exports and imports exceeds unity for a depreciating exchange rate toreduce the payments deficit. The textbook J-curve for a depreciating exchange rate recognizes that in the short run the payments deficit worsens (the downward part of the J-curve). The J-curve ultimately turns upwardbecauseit is assumedthat inthe long run price elasticities are approximately infinite
} 
If the payments imbalance is due to capital flows, there is a similar perverse effect. If, for example, country A is attracting a rapid net inflow of capital because investors in the rest of the world think the profit rate is higher in A, then the exchange rate will rise. This rising exchange rate creates the expectations of even higher profits for foreign investors and contrarily will encourage others to rush in with additional capital flows pushing the exchange rate even higher. If suddenly there is a change in sentiment (often touched off by some ephemeral event), then a fast exit bandwagon will ensue pushing the exchange rate perversely down.

\section{LIQUIDITY, UNCERTAINTY AND THE STABILITY OF MARKETS}

By providing liquidity in a world where the future can not be reliably predicted, financial markets can encourage savers to provide funding for durable investment projects that they would not furnish if their investment was illiquid. This characteristic of liberalized liquid financial markets is a Siren song for most developing nations whose desire for rapid economic growth requires attracting funds and resources in excess of what can be expected from domestic savings.

A liquid market, however, encourages each investor to believe in a fast exit strategy where the investor one can dose out one's position at little cost the moment he/she is dissatisfied with the way that matters are developing. A liquid market means that the asset holder has the "ability to reverse [immediately] a decision at the lowest possible transactions cost" (Bernstein, 1998a, p. 16). Developing economies, on the other hand, use the funds of international investors to develop durable assets that will substantially expand their real production capabilities into the indefinite future. These real investments are largely illiquid and irrevocable for the domestic economy (Keynes, 1936, pp. 150-1).

Financial assets typically represent liquid claims on expected future income streams generated by illiquid real investment projects. If today's market price is to reflect "fundamentals", then the market must use existing data to make a statistically reliably forecast of the entire future stream of quasi-rents associated with the underlying illiquid investment project. Strictly speaking, to make such a prediction requires one to draw samples from the future and calculate the statistical moments around the mean. Since this is impossible, efficient market theorists invoke (usually implicitly) the ergodic axiom. ${ }^{10}$ This ergodic presumption is that statistical averages calculated from existing historical cross-sectional or time series data provide reliable estimates of the same statistics that can be calculated from samples drawn in the future. Consequently, by invoking the ergodic axiom, EMT proponents are claiming that the future is merely the statistical shadow of the past. Accordingly, "rational" participants in an efficient market allocate

\footnotetext{
${ }^{10}$ For an explicit statement of the need for the ergodic axiom see Samuelson (1969) and Lucas and Sargent (1981).
} 
investment funds in those real projects that are "known" to provide the greatest real return in the future.

Keynes, on the other hand, took a dim view of the ability of people to reliably forecast the future in an uncertain world. Instead, market prices of liquid assets are dominated by a convention. "The essence of this convention - though it does not, of course, work out quite so simplylies in assuming that the existing state of affairs will continue indefinitely, except if we have specific reasons to expect a change" (Keynes, 1936, p. 152).

In normal times, the conventional wisdom is that financial markets are stable or at least have a high degree of built-in inertia. This simple-minded Keynesian convention has been translated by a highly sophisticated econometric technology into a search for unit roots and a random walk down Wall Street. Of course, if most market participants presume that the existing state of affairs will continue indefinitely (in the absence of evidence of a change in what people call market fundamentals), then most of the time financial market activity should be neither fragile nor destabilizing. But if the future is uncertain in the sense it can not be reliably predicted, doesn't this imply inherent fragility and instability?

In a letter, Keynes (1973, p. 137) admonished Joan Robinson saying "You must not confuse instability with uncertainty. It is true that the future... [is] uncertain but this does not mean that the present... is in a technical sense unstable". Market conditions will be stable in normal times as long as market participants expect there are no "surprises" in the near future.

Abnormal times of instability can readily occur, however, when the market's

"conventional valuation... is established as the outcome of the mass psychology of a large number of ignorant individuals, (then it) is liable to change violently as the result of a sudden fluctuation of opinion due to factors which do not really make much difference to the prospective yield... In abnormal times in particular, when the hypothesis of an indefinite continuance of the existing state of affairs is less plausible... the market will be subject to waves of optimistic and pessimistic sentiment which are unreasoning and yet in a sense legitimate where no solid basis exists for reasonable calculation.” (Keynes, 1936, p. 154)

In other words, sudden "surprises" can frighten investors sufficiently so that many seek a fast exit at the same time. The result can be catastrophic for any economy, but especially for developing economies where overseas investors are often alarmed by ephemeral events.

\section{LIQUIDITY AND ORDERLY MARKETS}

Financial markets furnish liquidity by providing an orderly environment where assets can be readily resold for cash. (The underlying real reproducible assets, 
however, do not possess the "essential [elasticity] properties" that Keynes associated with the attribute of liquidity ${ }^{11}$.) Market orderliness requires a private or a public institution, a "market maker", that regulates the net flows into and out of the market. Orderly liquid financial markets, however, encourage each investor to believe they can always make a fast exit (or entrance).

Orderliness, therefore, promotes the separation of ownership and controlmanagement (Keynes, 1936, pp. 150-1) (Davidson, 1972) (Bernstein, 1998a). With a liquid capital market, owners have no legal or moral commitment to stick around long enough to make sure their capital is used efficiently. If capital markets were completely illiquid then there would be no separation of ownership and control. Once capital is committed, the owners have an incentive to use the existing facilities in the best possible way no matter what unforeseen circumstances might arise. Perhaps then capital markets might behave more like the efficient markets of mainstream theory. ${ }^{12}$ Bernstein's (1998a, p. 23) homily that "An efficient market is a market without liquidity" is a lesson that policy makers must be taught. Especially in developing economies, policy makers must be made aware that liquidity can be the enemy of efficiency whenever events surprise foreign investors. Judicious use of capital controls can promote efficient use of capital resources by constraining any sudden change in the demand for liquidity that can adversely affect the real economy. Since financial markets are primarily organized to provide liquidity, then when bullish sentiment about the uncertain future dominates global financial markets, rising market prices encourage savers worldwide to readily provide the funding that induces entrepreneurial-investors to spend sums on new investment projects that (1) far exceeds their current incomes and (2) induce exuberant expectations of future returns. The result is an investment boom. If some time in the future, doubts suddenly arise concerning the reliability of these euphoric expectations, then bearish sentiment will come to the fore and the investment boom will turn into a bust.

When the bearish view of the future becomes overriding, an excessive demand for liquidity can develop that will impede the production of new investment capital even when real resources are idle and therefore readily available to produce new real capital goods. The basic message of Keynes's General Theory is that too great a demand for liquidity can prevent "saved" (i.e., unutilized) real resources from being employed in the production of investment goods. These resources will be involuntarily unemployed.

Unlike Old and New Keynesians, Keynes explicitly recognized that the introduction of sand in the wheels of liquidity-providing financial markets via a transactions

\footnotetext{
${ }^{11}$ Keynes (1936, p. 241n) argues that the attribute of liquidity of an asset is by no means independent of the presence of two essential properties, namely that the asset is not reproducible via the employment of labor and it is not substitutable for the producible output of industry.

12 In the absence of a liquid financial market " $[t]$ here is no object in frequently attempting to revalue an investment to which we are committed" (Keynes, 1936, p. 151) for there can be no fast exit strategy.
} 
tax is a double-edged sword. Keynes (1936, p. 160) noted that a financial transactions tax "brings us up against a dilemma, and shows us how the liquidity of investment markets often facilitates, though it sometimes impedes, the course of new investment". This is an especially important dilemma for developing economies. On the one hand, they usually recognize that liquidity in investment markets facilitates international financial inflows necessary to fund important real investment projects. On the other hand, this liquidity puts the real domestic economy (and the government policy makers) at the mercy of possible irrational fears of foreign investors. Once policy makers commit a national economy to the slippery road of using foreign funds to promote domestic investment projects, then, in an era of market liberalization, control over prosperity or depression is surrendered to foreigners who typically have little knowledge of the needs of the domestic economy.

\section{CONDITIONS FOR PROMOTING GROWTH AND FINANCIAL STABILITY}

What are the market conditions that in normal times create stable financial market prices? "It is interesting that the stability of the [financial] system and its sensitiveness... should be so dependent on the existence of a variety of opinion about what is uncertain. Best of all that we should know the future. But if not, then, if we are to control the activity of the economic system... it is important that opinions differ" (Keynes, 1936, p.172)

In other words, an ergodic system would provide the "best of all” possible worlds for financial market stability. Then the future can be reduced to actuarial certainty, i.e., "we should know the future". Market efficiency would be assured as long as agents operated in their actuarially known self-interest. There would be no need for a fast exit strategy.

If the system is nonergodic, however, then actuarial certainty and the possibility of rational probabilistic risk spreading which, according to New Classical and New Keynesian economists, is an essential function of efficient markets, is impossible. Nevertheless, market stability is possible if substantial numbers of market participants either (1) hold continuously differing expectations about the future or (2) believe the current price is the correct price and that there is a credible institution that will take whatever steps are necessary to assure non-volatile changes in the (correct) current price. Under these conditions, any small upward change in the market price brings about a significant bear reaction, while any slight downturn induces a bullish reaction. The result is to maintain spot financial market (resale) price orderliness over time and therefore a high degree of liquidity. ${ }^{13}$

\footnotetext{
${ }^{13}$ Only in the nonergodic world that is our entrepreneurial economic system, is it sensible to organize complex and lengthy production and exchange processes via the use of nominal contracts (Davidson, 1994) in order to give entrepreneurs some control of cash flows over an otherwise uncertain future. In such a world, the primary function of organized financial markets is to provide liquidity by permitting the resale of assets in an orderly market. Only secondarily do modern super-efficient financial markets
} 


\section{IRRATIONAL EXUBERANCE AND BANDWAGON BEHAVIOR}

If at any time increased volumes in financial markets are associated with the "irrational exuberance" behavior that central banker Alan Greenspan once spoke of, then many similar thinking "irrational" participants suddenly will have dominated the market. If there is a sudden market swing to a bandwagon consensus, then there is an abrupt lack of market participants with differing expectations about the future. Liquidity can dry up until there is a sufficiently large movement in the market price to break down the bandwagon consensus mentality and create a diversity of bullbear views. In the meantime, the impact on the real economy can be devastating.

Accordingly, whenever there is a sudden shift in the private-sector's bull-bear disposition, what I call a bandwagon effect ${ }^{14}$, then price stability requires capital regulations to prevent the bears from liquidating their position too quickly (or the bulls from rushing in) and overcoming any single agent (private or public) who has taken on the responsible task of market maker to promote "orderliness". Capital controls serve the same function as laws that make it a crime to yell fire in a crowded theater. In the absence of such social constraints on free speech, the resulting rush to the exit may inflict more damage than any potential fire. In the absence of laws permitting governments to invoke capital controls to prevent a crush due to fast exit (or entry), unruly financial market behavior can inflict severe damages to innocent bystanders.

In the absence of a credible market maker with sufficient liquid resources and/ or regulatory controls to stem a bandwagon, enterprise becomes the bubble on the whirlpool of speculation (Keynes, 1936, p. 159). Disruptive speculation involves sharp and profound changes in the ex post moving average secular trend. ${ }^{15}$

Bandwagons are induced often by some "surprising" event that encourages portfolio holders to expect that others will now expect a change in the exchange rate. If an institution can be developed that assures portfolio managers that exchange rates will be stable over time no matter what unforeseen events occur, then this will do more to inhibit speculative short-term round tripping than any small Tobin tax. Conventional wisdom is that if the psychology of the market is not changing there will be an inertia in market valuations. ${ }^{16}$ Accordingly, a policy designed to reducing, if not eliminating, disruptive speculation must involve

affect the allocation of new capital amongst industries and to the extent it apportions capital, this distribution is not predetermined by some long-run immutable real economic fundamentals.

${ }^{14}$ Some speak of a "herd" effect. But except for moments of stampede, herds are usually docile and tend to move slowly from one grazing place to another.

15 The dictionary defines secular as "lasting from century to century".

${ }^{16}$ Ex post one can always calculate a moving avenge for any time series of market prices and, if one accepts what Samuelson has called the ergodic hypothesis, the resulting market valuation over time can be attributed to being determined by some underlying "fundamental". 
building institutions that assure market participants that the "correct" market psychology is a belief in a persistent, stable (moving average) trend in market prices over time. ${ }^{17}$ For example, if market participants believe that a market maker exists who can guarantee an unchanging spot market price (or changing only within very small boundaries) over time under preannounced and readily understood rules of the game, then the existence of this credible market maker provides an anchor for "market psychology". For participants to believe in the market maker's ability to maintain the target market price trend, however, the market maker must have a sufficient inventory of money and the asset that is being sold in the market. In a foreign exchange market for example, this implies that the domestic monetary authority has credibility (and a sufficient inventory of foreign reserves or easy access to additional reserves) and has announced that it will use its reserves to maintain an orderly market at the "proper" exchange rate. That is the explanation of why currency boards with reserves equal to the domestic money supply can fix the exchange rate and, in normal times, can maintain the exchange rate.

To prevent disruptive speculation requires a buffer stock policy practiced by a market maker and the power to institute financial flow regulations. The majority of market participants must believe in the institution's ability to enforce civilized behavior similar to the prohibition of not yelling fire in a theatre. Then any speculation that occurs will be small "bubbles on a steady stream of enterprise" (Keynes, 1936, p. 159).

Such considerations led Keynes to suggest an outright prohibition of all "hot money" international portfolio flows through the creation of a supranational central bank and his bancor plan. At this stage of economic development and global economic integration, a supranational central bank is not politically feasible. Accordingly what should be aimed for is a more modest goal of obtaining an international agreement among the major trading nations that insures orderly international monetary markets. To be economically effective and politically feasible, this agreement, while incorporating the economic principles thar Keynes laid down in his bancor plan, should not require any nation to surrender control of local banking systems or its domestic fiscal policies.

\section{POLICY RECOMMENDATIONS}

The function of capital controls is to prevent sharp changes in the bull-bear sentiment from overwhelming a market maker and inducing rapid changes in pri-

\footnotetext{
${ }^{17}$ In fact, all markets in liquid assets require the institution of one or more credible "market makers" who follow some preannounced rules of the game to assure orderliness in the market. The more orderly the market maker keeps the market, the less the moment-to-moment volatility. It is only when market makers fail in their responsibility to maintain orderly markets that volatility becomes disorderly, and speculation can have real disruptive effects.
} 
ce trends, for such volatility, especially in foreign exchange markets can have devastating real consequences.

There is a spectrum of different capital controls available. At one end of the spectrum are controls that primarily impose administrative constraints either on a caseby-case basis or expenditure category basis. These controls include administrative oversight and control of individual transactions for payments to foreign residents (or banks) often via oversight of international transactions by banks or their customers. ${ }^{18}$ Other capital controls include (a) policies that make foreign exchange available but at different exchange rates for different types of transactions and (b) the imposition of significant taxes (or other opportunity costs) on specific international financial payments, e.g., Chilean speed bumps or the 1960s United States Interest Equalization Tax which discriminated against foreign securities being sold in domestic markets. Finally, there can be many forms of monetary policy decisions undertaken to affect international payment flows, e.g., raising the interest rate to slow capital outflows, raising bank reserve ratios, limiting the ability of banks to finance purchases of foreign securities, and regulating interbank activity.

The experience of the IMF, as lender of last resort imposing the same conditions on all the Asian contagion nations requiring international liquidity loans, should have taught us that in discussing policy prescriptions one size does not fit all. Accordingly, the type of capital regulations a nation should choose from the spectrum of tools available will differ depending on the specific circumstances involved. In this brief paper it would be presumptuous of me to catalog what capital regulations should be imposed for any nation under any given circumstances. Nevertheless, it should be stressed that regulating capital movements is a necessary, but not sufficient, condition for promoting global prosperity.

Elsewhere (Davidson, 1992, 1994, 1997) I have developed in detail a proposal for reforming the entire international payments system via an international clearing union that provides for capital controls and other necessary and sufficient conditions to permit the establishment of a golden age in the 21 st century. The main provisos of my proposal are:

1. The unit of account and ultimate reserve asset for international liquidity is the International Money Clearing Unit (IMCU). All IMCU's are held only by central banks, not by the public.

2 . Each nation's central bank is committed to guarantee one way convertibility from IMCU deposits at the clearing union to its domestic money. Each

\footnotetext{
${ }^{18}$ Mayer (1998, pp. 29-30) has argued that the Asian problem was due to the international interbank market that created the whirlpool of speculation and that what is needed is a "system for identifying... and policing interbank lending" and banks' contingent liabilities resulting from dealing in derivatives. Echoing our nonergodic theme, Mayer (1998, p. 31) declares "The mathematical models of price movements and covariance underlying the construction of these (contingent liabilities simply collapsed as actual prices departed so far from 'normal' probabilities".
} 
central bank will set its own rules regarding making available foreign monies (through IMCU clearing transactions) to its own bankers and private sector residents. ${ }^{19}$ Ultimately, all major private international transactions clear between central banks' accounts in the books of the international clearin $g$ institution.

3. The exchange rate between the domestic currency and the IMCU is set initially by each nation - just as it would be if one instituted an international gold standard.

4. Contracts between private individuals will continue to be denominated into whatever domestic currency permitted by local laws and agreed upon by the contracting parties.

5. An overdraft system to make available short-term unused creditor balances at the Clearing House to finance the productive international transactions of others who need short-term credit. The terms will be determined by the pro buono clearing managers.

6. A trigger mechanism to encourage a creditor nation to spend what is deemed (in advance) by agreement of the international community to be "excessive" credit balances accumulated by running current account surpluses. These excessive credits can be spent in three ways: (1) on the products of any other member of the clearing union, (2) on new direct foreign investment projects, and/or (3) to provide unilateral transfers (foreign aid) to deficit members.

7. A system to stabilize the long-term purchasing power of the IMCU (in terms of each member nation's domestically produced market basket of goods) can be developed. This requires a system of fixed exchange rates between the local currency and the IMCU that changes only to reflect permanent increases in efficiency wages. ${ }^{20}$ This assures each central bank that its holdings of IMCUs as the nation's foreign reserves will never lose purchasing power in terms of

${ }^{19}$ Correspondent banking will have to operate through the International Clearing Agency, with each central bank regulating the international relations and operations of its domestic banking firms. Small scale smuggling of currency across borders, etc., can never be completely eliminated. But such movements are merely a flea on a dog's back -a minor, but not debilitating, irritation. If, however, most of the residents of a nation hold and use (in violation of legal tender laws) a foreign currency for domestic transactions and as a store of value (e.g., it is estimated that Argentineans hold more than $\$ 5$ billion U.S. dollars), this is evidence of a lack of confidence in the government and its monetary authority. Unless confidence is restored, all attempts to restore economic prosperity will fail.

${ }^{20}$ The efficiency wage is related to the money wage divided by the average product of labor, it is the unit labor cost modified by the profit mark-up in domestic money terms of domestically produced GNP. At this preliminary stage of this proposal, it would serve no useful purpose to decide whether the domestic market basket should include both tradable and non-tradable goods and services. (With the growth of tourism more and more non-tradable goods become potentially tradable.) I personally prefer the wider concept of the domestic market basket, but it is not obvious that any essential principle is lost if a tradable only concept is used, or if some nations use the wider concept while others the narrower one. 
foreign produced goods, even if a foreign government permits wage-price inflation to occur within its borders.

8. If a country is at full employment and still has a tendency towards persistent international deficits on its current account, then this is prima facie evidence that it does not possess the productive capacity to maintain its current standard of living. If the deficit nation is a poor one, then surely there is a case for the richer nations who are in surplus to transfer some of their excess credit balances to support the poor nation. ${ }^{21}$. If it is a relatively rich country, then the deficit nation must alter its standard of living by reducing the relative terms of trade with major trading partners. If the payment deficit persists despite a continuous positive balance of trade in goods and services, then there is evidence that the deficit nation might be carrying too heavy an international debt service obligation. The pro buono officials of the clearing union should bring the debtor and creditors into negotiations to reduce annual debt service payments by [1] lengthening the payments period, [2] reducing the interest charges, and/or [3] debt forgiveness. ${ }^{22}$

Proviso \#2 permits capital controls. Proviso \#6 embodies Keynes's innovative idea that whenever there is a persistent (and/or large) imbalance in current account flows - whether due to capital flight or a persistent trade imbalance -, there must be a built-in mechanism that induces the surplus nation(s) to bear a major responsibility for eliminating the imbalance. The surplus nation must accept this burden for it has the wherewithal to resolve the problem.

In the absence of \#6, under any conventional system, whether it has fixed or flexible exchange rates and/or capital controls, there will ultimately be an international liquidity crisis (as any persistent current account deficit can deplete a nation' $\mathrm{s}$ foreign reserves) that unleashes global depressionary forces. Thus, proviso \#6 is necessary to assure that the international payments system will not have a built-in depressionary bias. Ultimately then it is in the self-interest of the surplus nation to accept this responsibility, for its actions will create conditions for global economic expansion some of which must redound to its own residents. Failure to act, on the other hand, will promote global depressionary forces that will have some negative impact on its own residents.

Some think that my specific clearing union plan, like Keynes's bancor plan, a half century earlier, is Utopian. But if we start with the defeatist attitude that it is too difficult to change the awkward system in which we are trapped, then no pro-

\footnotetext{
21 This is equivalent to a negative income tax for poor fully employed families within a nation.

22 The actual program adopted for debt service reduction will depend on many parameters including: the relative income and wealth of the debtor vis-à-vis the creditor, the ability ofthe debtorto increase its per capita real income, etc.
} 
gress will be made. Global depression does not have to happen again if our policy makers have sufficient vision to develop this Post-Keynesian approach. The health of the world's economic system will simply not permit us to muddle through.

\section{CONCLUSION}

Liquid markets can not be expected to be efficient. In an uncertain world, it is not surprising therefore that liberalized international financial markets have undergone so many currency (liquidity) crises in recent years.

Conventional mainstream wisdom, if and when it recognizes the possibility of currency crises in an efficient market model, usually rationalizes the appearance of such international liquidity crises as a necessary disciplinary device. For example, DeAngelis (1999-2000) argues that in "the context of a global economy geared towards production for profit, liquidity crunches have a systemic function in that they help ensure the standards of competitiveness or movements towards further global integration are enforced".

In other words, as classical economists have always claimed, recessions and depressions are a good laxative for the economic system as they cleansed the economic body of the inefficiencies that have built up in an era of prosperity. A classic example of this classical prescription is revealed in the memoirs of Herbert Hoover. Treasury Secretary Andrew Mellon always offered the same advice to President Hoover. "Mr. Mellon had only one formula. Liquidate labor, liquidate stocks, liquidate the farmer, liquidate real estate. It will purge the rottenness out of the system... People will work harder, lead a more moral life.” (Hoover, 1952, p. 30) Today's conventional wisdom espoused by the IMF and many other mainstream economists still affirms Mellon's puritanical cathartic view of the value of a liquidity crisis.

On the other hand, Keynes believed that a liquidity crunch was not a necessary purgative for restoring economic health. Rather liquidation processes and the resulting unemployment involved a "public scandal of wasted resources" (Keynes, 1936, p. 381). Keynes believed that the two major faults of the entrepreneurial system in which we live are "its failure to provide for full employment and its arbitrary and inequitable distribution of income and wealth". He claimed that his "general theory" had an important "bearing" on ameliorating both these "outstanding faults" (Keynes, 1936, p. 372).

In the closed economic system of his General Theory, Keynes (1936, p. 379) insisted that his analysis "is moderately conservative in its implications. For whilst it indicates the vital importance of establishing central controls [over the level of effective demand]... there are wide fields of activity which are unaffected". Our argument has extended Keynes's principle of effective demand to an open economy setting. In an open system, changes in the exchange rate affect the level of aggregate demand for domestically produced goods through its impact on exports and imports, the interest rate and the rate of domestic investment. Accordingly, Keynes's 
principle of effective demand indicates (1) the need for central controls over the exchange rates and (2) international agreements that place the major responsibility for resolving international payments imbalances on the creditor nation(s). Only then, will Keynes's "moderately conservative" analysis point the way to a golden age for the global economic system of the 21st century.

\section{REFERENCES}

ADELMAN, I. “Long term economic development”, Working Paper No. 589, California Agricultural Experiment Station, Berkeley, March 1991.

BERNSTEIN, P. L. Against The Gods, New York, Wiley, 1996.

BERNSTEIN, P. L. "Stock market risk in a Post Keynesian world", Journal of Post Keynesian Economics, 21, 1998a.

BERNSTEIN, P. L. "Why the efficient market offers hope for active management", Keynote address to the European Feder7ation of Financial Analysts Society, September 1998b.

BERNSTEIN, P. L. "Risk, Time. Reversibility”, 22nd Annual Lecture of The Geneva Association, October $1998 \mathrm{c}$.

DAVIDSON, P. Money and the Real World. Macmillan, London, 1972.

DAVIDSON, P. "Rational Expectations: A Fallacious Foundation for Studying Crucial DecisionMaking Processes", Journal of Post Keynesian Economics 5, Winter 1982-3.

DAVIDSON, P. “Reviving Keynes's revolution”, Journal of Post Keynesian Economics, 6, 1984.

DAVIDSON, P. "Reforming the world's money”, Journal of Post Keynesian Economics, 15, 1992.

DAVIDSON, P. Post Keynesian Macroeconomic Theory. Cheltenham, Elgar, 1994 .

DAVIDSON, P. "Are grains of sand in the wheels of international finance sufficient to do the job when boulders are often required?”, The Economic Journal, 107, 1997.

DAVIDSON, P. "Volatile financial markers and the speculator", Economic Issues, 3, 1998.

DEANGELIS, M. "Capital movements, Tobin tax and permanent fire prevention”, Journal of Post Keynesian Economics, 22, 1999-2000, forthcoming.

EICHENGREEN B., TOBIN, J., and WYPLOSZ, C. "The case for sand in the wheels of international finance", The Economic Journal, 105, 1995.

FELIX, D. “ On drawing policy lessons from recent Latin America currency crises”, Journal of Post Keynesian Economics, 20, 1997-8.

FISCHER, S. "On the need for an international lender of last resort" , paper delivered to American Economic Association, 1999.

FRIEDMAN, M. “Markets To The Rescue”, The Wall Street Journal, October 13, 1998.

HOOVER , H. The Memoirs of Herbert Hoover; The Great Depression 1929-1941 Macmillan, New York, 1952.

KEYNES, J.M. The General Theory of Employment Interest and Money. Harcourt Brace, New York, 1936.

KEYNES, J.M..”The General Theory”, Quarterly Journal of Economics (1937), reprinted in Collected Works of John Maynard Keynes, 14, ed. by D. Moggridge, London, Macmillan, 1973. All references are to the reprint.

LUCAS, R. E. and SARGENT, T. J. Rational Expectations and Econometric Practices Minneapolis, University of Minnesota Press, 1981.

MAYER, M. “The Asian Disease: plausible diagnoses, possible remedies”, Levy Institute Public Policy Brief n. 44, 1991.

PINDYCK, R. S. "Irreversibility, uncertainty and investment" , Journal of Economic Literature, 29, 1991.

SAMUELSON, P. A. Foundations of Economic Analysis, Cambridge, Harvard University Press, 1947. 
SKIDELSKY, R. "Historical reflections on capital movements" in Capital Regulation: For and Against, the Social Market Foundation, London, 1999.

STIGLITZ, J. E. "Using tax policy to curb speculative short-term trading”, Journal of Financial Services, 3, pp. 101-113, 1991.

SUMMERS , L. H., and SUMMERS, V. P., "When financial markets work too well: a cautious case for a securities transactions tax", Journal of Financial Services, 3, 1989.

TOBIN, J. "The new economics one decade older", The Janeway Lectures on Historical Economics. Princeton, Princeton University Press, 1974. 